\title{
Equilibrium
}

Quarterly Journal of Economics and Economic Policy

VOLUME 7 ISSUE 4, 2012

ISSN 1689-765X

Joanna Hernik*

West Pomeranian University of Technology, Poland

Dana-Nicoleta Lascu

University of Richmond, Robins School of Business, USA

\section{An Analysis of Social Campaigns Aimed at Reducing Alcohol Consumption: The Case of Poland}

\section{JEL Classification Codes: M37, E21}

Keywords: advertising effectiveness, alcohol demarketing, emerging markets, national advertising campaigns

\begin{abstract}
Poland is currently grappling with a challenging situation: as salaries are increasing and more consumers can afford to purchase alcohol, alcoholic consumption in Poland is among the highest in the European Union. Specifically, the market for vodka alone currently stands at $\$ 347$ million, and beer at $\$ 465.2$ million. In response to these developments, the Polish government has levied high taxes on alcohol consumption and enacted some of the most stringent advertising laws for alcoholic products in the European Union. It also launched nine national advertising campaigns and a local campaign in the West-Pomeranian region and increased the excise tax on alcohol. The current study attempts to shed light on the campaigns and to offer insights into the different themes that the campaigns use to persuade consumers to limit their alcohol consumption and to act responsibly when consuming alcohol and to offer actionable solutions to change the alcohol-related consumption behavior in Poland through warning labels, health education, and other attempts at demarketing alcohol consumption. The paper also examines
\end{abstract}

(C) Copyright Nicolaus Copernicus University Press

Date of Submission: August 21, 2011; date of acceptance: April 18, 2012

* Contact: e-mail: joanna.hernik@ @ut.edu.pl, Zachodniopomorski Uniwersytet Technologiczny w Szczecinie, Wydział Ekonomiczny, Katedra Marketingu, ul. Żołnierska 47, 71-210 Szczecin, Poland 
alternative venues that might lead to a change in the alcohol-related consumption behavior for Polish consumers, which may include instituting warning labels and other counter advertising to educate the public with regard to alcohol-related risks, and thus curb the overall alcohol consumption and related negative outcomes for the Polish consumers.

\section{INTRODUCTION}

Poland is a top consumer of alcohol in the European Union, even though it levies high taxes on alcohol consumption and has stringent advertising laws for products containing alcohol. What is particularly disconcerting is that alcohol consumption is increasing, as Poles' salaries have been increasing and more consumers can afford to purchase higher quantities of the product. The present study examines all the current national advertising campaigns in Poland (nine in number), some of which have been initiated over ten years ago, and a local campaign in the West-Pomeranian region, and offers insights into the themes used to persuade consumers to limit their alcohol consumption and to act responsibly when consuming alcohol. The paper also offers actionable suggestions that might change alcohol-related consumption behavior for Polish consumers, such as instituting warning labels and other counteradvertising to educate the public with regard to alcohol-related risks, and thus curb alcohol consumption.

Alcoholic drinks are the tranquilizer of choice in many cultures and traditions, providing relaxation and facilitating social interaction; but excessive alcohol consumption produces externalities of unknown proportions in terms of high medical costs, fires, and result in a burden on social services (Orenstein, Hanssens 1985). In Poland, the spirit drinks consumption per capita is high, with the market for vodka at $\$ 347$ million, wine at $\$ 59$ million, and beer at $\$ 465.2$ million (www.money.pl 2011); in fact, per capita consumption of alcohol in Poland is higher compared to most European countries (Poel et al. 2010). In 2008, the Polish government increased the excise tax on spirits by $9 \%$, levying an excise rate of about 11 Euros per liter of pure alcohol, which has resulted in a substantial consumption volume decline the estimated range of decline was between $6.5 \%$ to $12.5 \%$, but consumers continued to spend 3.7 billion Euros on spirit drinks (Poel et al. 2010).

Many countries have made attempts to minimize these costs by means of alcohol control laws (Ornstein, Hanssens 1985). In the European Union, legislation on alcohol advertising focuses primarily on the protection of minors, banning all audiovisual commercial communications for alcoholic beverages to minors, as well as any encouragement of immoderate consumption (Poel et al. 2010). In addition to these common rules, EU Member States are free to impose more stringent restrictions on alcohol advertising and market- 
ing. For example, Ireland, Austria and France have legally banned spirits advertising on television and radio, whereas, in Poland (and in Sweden, Slovenia, and Finland), advertising rules are even more stringent: the advertising of spirits is almost completely banned (Poel et al. 2010).

\section{POLISH ALCOHOL CONSUMPTION}

Yet, despite strict controls on marketing communications in Poland, the spirit drinks consumption per capita is high. In 2010, the Polish market for vod$\mathrm{ka}$ was at $\$ 347$ million, wine at $\$ 59$ million, and beer at $\$ 465.2$ million (www.money.pl 2011), and 5\% of Poles drinks moonshine, and 12\% drink homemade wine (Central Statistical Office 2009). About $80 \%$ of the adult population drinks alcohol, and addiction is at 3\%; drinking at home accounts for $61 \%$ of beer consumption, $70 \%$ of vodka, $80 \%$ of wine (Central Statistical Office 2009). See Figures 1 and 2. In fact, per capita consumption of alcohol in Poland is higher compared to most European countries: while in most European countries the average consumption per capita is 5 liters of sprits per year, for Poland, the consumption is 8 liters of spirits per year (Poel et al. 2010). And, in addition to the public figures, in Poland there is also a sizable black market, estimated to be at about 10\% (Poel et al. 2010).

Figure 1. Per Capita Pure Alcohol Consumption in Poland (in gallons)

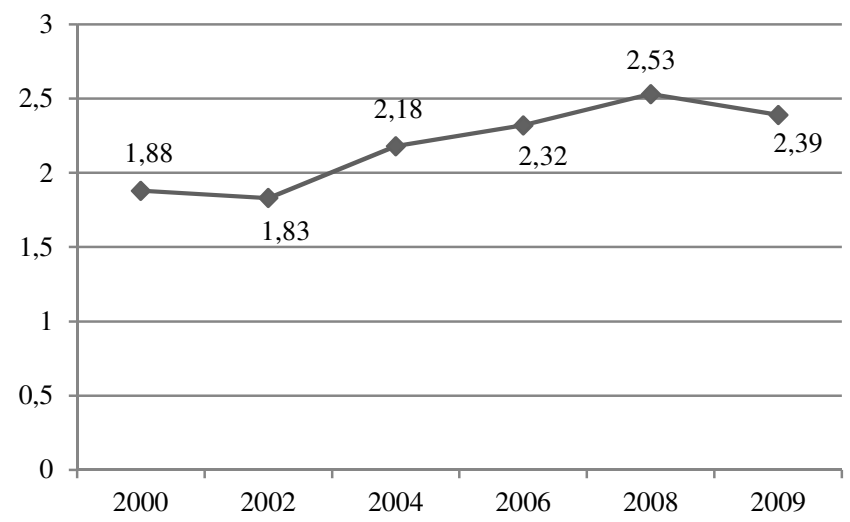

Source: Adapted from the State Agency for Solving Alcohol Problems, http://www .parpa.pl/index.php?option=com_content\&task=view\&id=156\&Itemid=145 (21.5.2011). 
Poland produces $84,535,056$ gallons of alcoholic beverages yearly, imports 9,774,365 gallons years, and consumes 83,742,540 gallons of alcoholic beverages yearly (Poel et al. 2010). As such, Poland is one of the larger producers of alcoholic beverages in Europe, and the largest producer of vodka in the European Union. Poland's vodka production dates back to the Middle Ages, when vodka was used for medicinal purposes, to increase libido and fertility - some of the Polish brands on the market today date back to the $16^{\text {th }}$ and $17^{\text {th }}$ centuries (Poel et al. 2010). It employs 93,200 employees in the production and sale of spirit drinks, and government revenues from the production and sale of spirit drinks is 2.6 billion Euros yearly (Poel et al. 2010).

Figure 2. Structure of Alcohol Consumption in Poland [in \%]

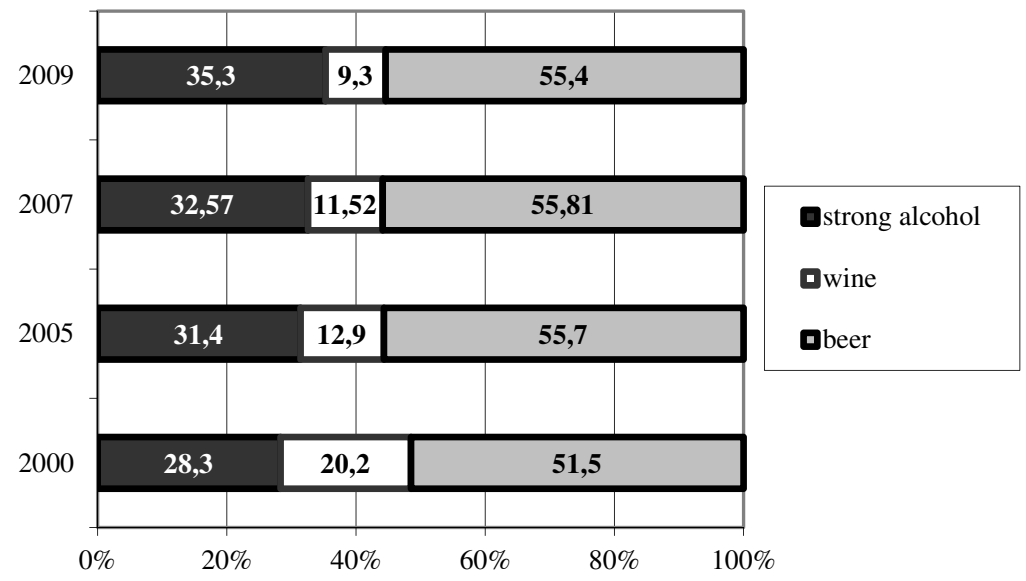

Source: Adapted from the State Agency for Solving Alcohol Problems, http://www.parpa.pl/ index.php?option=com_content\&task=view\&id=156\&Itemid=145 (21. 05.2011).

And, as Poland is making rapid gains in its path to economic prosperity, its consumption of alcohol appears to grow. The Gross National Income (GNI) per capita was at $\$ 18,440$ in 2009 , increasing rapidly - up from $\$ 12,590$ in 2004 (World Bank 2011). And a rapid increase in income has clearly influenced the consumers' ability to purchase alcohol - see Figure 3. 
Figure 3. Number of Bottles of Vodka, Beer and Wine a Customer Can Buy for an Average Yearly Salary

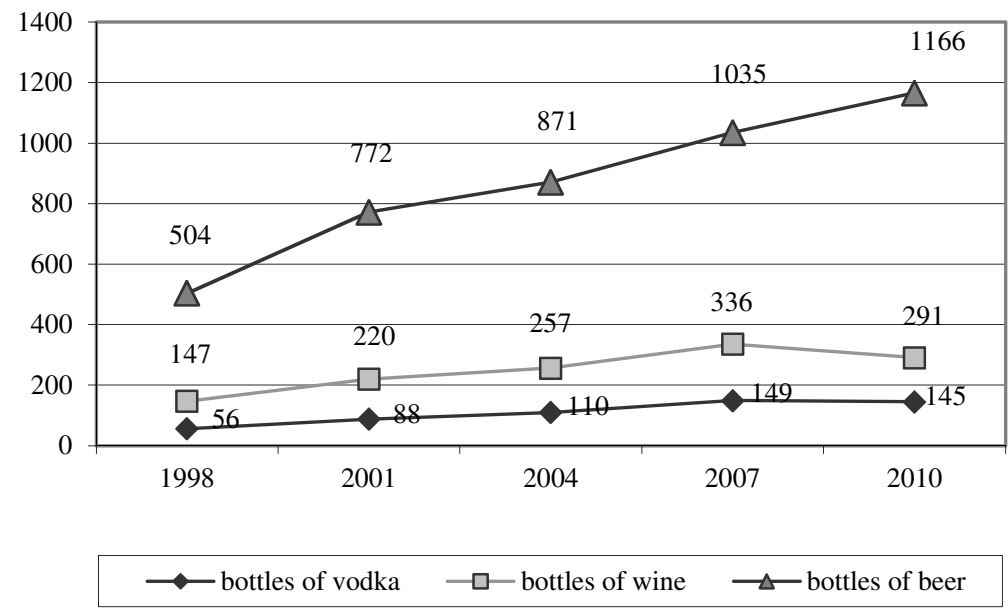

Source: Adapted from the State Agency for Solving Alcohol Problems, http://www.parpa .pl/index.php?option=com_content\&task=view\&id=156\&Itemid=145 (5/21/2011.).

\section{GOVERNMENT INITIATIVES}

\section{TO CONTROL ALCOHOL CONSUMPTION}

One approach to controlling increasing alcohol consumption is to increase the cost of alcohol for the consumer by increasing taxes. In 2008, the Polish government increased the excise tax on spirits by $9 \%$, levying an excise rate of about 11 euro per liter of pure alcohol, which has resulted in a substantial consumption volume decline - the estimated range of decline was between 6.5 to $12.5 \%$ (Poel et al. 2010). Nevertheless, in 2009, consumers continued to spend 3.7 billion euro on spirit drinks, which materialized in considerable revenues for the government, namely 1.5 billion euro in excise revenues and 667 million euro in VAT revenues (Poel et al. 2010).

Another approach to controlling alcohol consumption involves creating awareness campaigns that influence consumers to engage in responsible consumption behaviors. Demarketing actions, such as advertising campaigns against smoking and drinking, have greatly contributed to the decrease in the undesirable behavior and has led to the development of negative stereotypes of that behavior (Moore 2005). There are many who advocate the use of alcohol warning labels and messages (or counteradvertising) as effective 
tools to educate the public about alcohol-related risks and to help curb alcohol consumption (Bang 1998). Prior studies on alcohol warning messages suggest that their effectiveness is limited to a modest increase in consumer awareness, especially in young adults and heavy users of alcohol (Mazis, Morris, and Swasy 1991; Bang 1998). An awareness increase is particularly reported among men, people 18-29 years of age, heavy drinkers, and those with more education (Scammon, Mayer, and Smith 1991; Graves 1993), and adolescents (MacKinnon 1993; Bang 1998).

Evidence to date, however, suggests that the receiver effects of alcohol warning messages are scant and inconsistent at best (Hilton 1993; Bang 1998). One study that reported a positive impact on behaviors acknowledged that the effects might have resulted from factors (e.g., peer pressure-oriented public campaigns) other than the awareness of alcohol warnings (Graves 1993; Bang 1998). It is also possible that there are mediating factors involved: those with a more favorable attitude toward alcohol consumption tend to disbelieve specific instance warnings (Andrews, Netemeyer, and Durvasula 1991); Bang 1998). Moreover, studies found that certain persons actually drink more or start drinking after being told that, to avoid risks, they should not drink (Andrews 1995; Bang 1998). Therefore, evidence from prior empirical studies seems to fail to support the critics' argument that alcohol warning messages are useful educational tools to inform the public of alcohol-related dangers (Bang 1998). In the next section, we examine Poland's current advertising campaign to reduce drinking and its negative effects on consumers and society.

\section{STUDY}

A study was conducted to assess the different communication campaigns used in Poland to control excessive drinking. There are currently nine national campaigns and several regional campaigns aimed at changing individuals' alcohol-consumption-related behavior. In this study, we examine the nine campaigns and offer insights into the themes used, and the strategies used to change consumer behavior. The authors examined posters and other advertising materials used to communicate with target audiences, and examined various sources of information about the advertisements and their sponsors. The campaigns are discussed below, and the findings are summarized in the next section, entitled "Emerging Campaign Themes."

"Drinking? Do not leave!" - This advertisement (ill. 1) portrays men attending a birthday party. The ad starts with a traditional Polish party song titled "To One Hundred Years," but, instead, it substitutes the statement "Even 100 years will be not enough to pay for other people's lives... Think 
about it before you drive drunk and kill somebody." The advertisement is in bold black and red, symbolizing the colors of a prison and blood, and it portrays prison corridors. This campaign was initiated by National Council of Traffic Safety, an advisory body of the Polish government, which cosponsored it with the Polish National Police Main Department and Association of Spirits Industry Employers (www.pilesniejedz.pl 2010. The total cost for the 2-month-long campaign - from September 16 until November 15 was $\$ 1,041,558$, and it consisted of 145,000 fliers, 50 doormats placed in the most popular pubs, 100 bus ads covering the entire back, TV and cinemas advertisements and a simulator in the capital city, Warsaw, showing a car overturning for drivers who drive too fast (www.pilesniejedz.pl 2010).

Illustration 1. "I'm sober, I can drive" and "I am driving sober!" posters
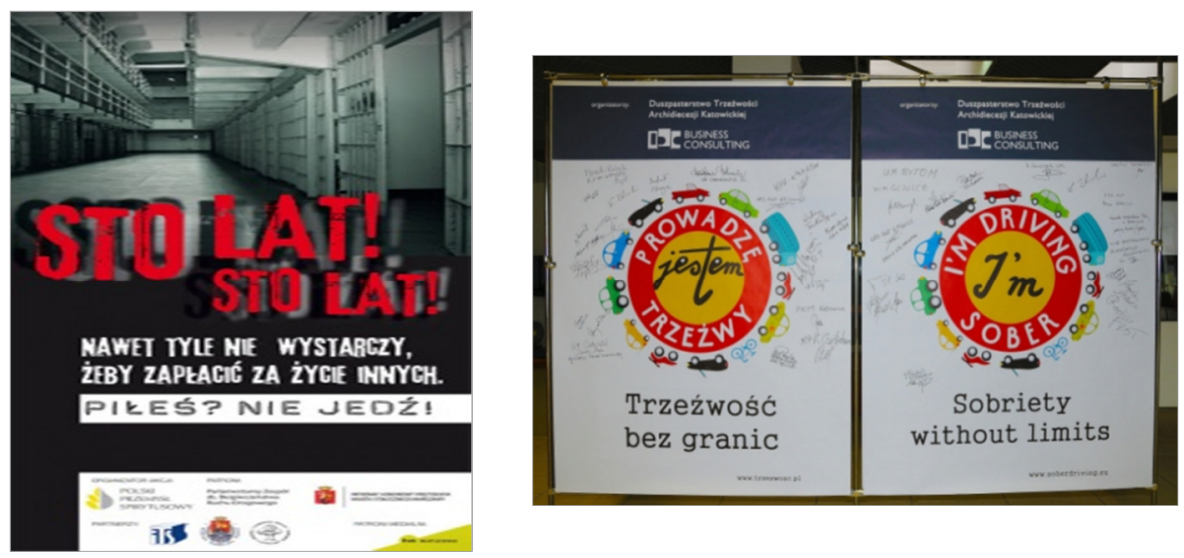

Source: http://www.pilesniejedz.pl/ and http://www.trzezwosc.pl/.

Next example, "I Am Driving Sober!" campaign argues that sobriety is a natural, universal, and trendy behavior. It appeals, first of all, to positive values inherent in the nature of every human being. This campaign is created at the initiative of a Catholic priest, Piotr Brząkala, in a long-standing cooperation with the Business Consulting Company, a digital printing house; the campaign promotes the idea of a sober, conscious life (www.trzezwosc.pl 2011). The plan is to create a Pan-European campaign on this theme. In 2010, Polish firm Eurovia S.A. picked up on the theme and printed posters, a pendant for women's bags, and a logo (www.trzezwosc.pl 2011). The campaign started in 2010 and was broadcast in July and August - August is traditionally "a month without alcohol" for all Catholics in Poland. In War- 
saw, "I am driving sober!" was promoted on 50 trams using the campaign's logo. In 2009, there were a total of 165 billboards (ill. 1), 400 bus posters 18 cities, 200 trams, and 26500 labels on cars (www.trzezwosc.pl 2011).

Swimming under the influence of alcohol is one of the top reasons for drowning in Poland. That's why the campaign "I Swim Without Alcohol in My Blood" stresses that swimming, even after very small drink, increases a threat of loss of balance, may cause thermal shock, limiting one's ability to recognize danger. The ad was created by the association of Polish Vodka in cooperation with the Polish Yachting Association and the Water Rescue Association (http://plywambezpromili.pl). Posters were placed at sea resort areas and in places close to lakes and river beaches, informing about the dangers connected with water sports and alcohol consumption. The campaign started in 2007 and took place every August, when most Polish families spend time by the seaside. The main text of the campaign states that: "Swimming under the influence of alcohol may be a reason of accidents and even drowning" (http://plywambezpromili.pl). In the summer of 2010, of the almost 400 people who drowned in Poland, 200 had their death attributed to alcohol (wiadomosci.gazeta.pl)*.

The campaign titled "Appearances Can Be Deceptive; One's ID Is Not" started in 2009 and continued in 2010. Its main goal is to persuade sellers to check young people's ID, to make sure that they are over 18 years old if they purchase alcohol. The campaign uses television advertising to show that one's appearance may be deceiving, that one may be in fact younger than 18 and purchase alcohol. During this campaign, policemen visited sellers to remind them about the law, giving out stickers, posters and fliers (www.browary-polskie.pl 2011). The campaign was financed by the Union of Brewing Industry Employers, and conducted in cooperation with the Polish National Police Main Department (www.browary-polskie.pl 2011).

Check If Your Drink Is Safe - this long-standing campaign in Poland was organized by the Polish State Agency for Resolving Alcohol Problems (http://www.wyhamujwpore.pl 2011). They used television and radio advertising, posters and billboards, and the Internet to inform people that, even if they are not fully addicted to alcohol, drinking can provoke serious health problems. The Agency described as the main aim of this campaign to limit the impact of alcohol on health, and on society in general, and it addressed the economic costs connected with alcohol abuse. The ad stresses that only $3-5 \%$ of alcoholics are destitute individuals with nothing to lose if they

* The tragic record: almost 400 people drowned in the summer, http://wiadomosci.gazet a.pl/Wiadomosci/1,80708,8333679,Tragiczny_rekord_w_wakacje_utonelo_prawie_400_oso b.html. 
drank, and that the rest of alcohol abusers are average Poles, most of whom hide their inclination to alcohol because they believe it is not dangerous (http://www.wyhamujwpore.pl 2011). The logo consists of an inverted glass and a fist as a sign of resistance. The dominant colors are again black and red and the slogan is "break in time!"

Illustration 2. "Appearances Can Be Deceptive; One's ID Is Not" and "Break in time!" posters
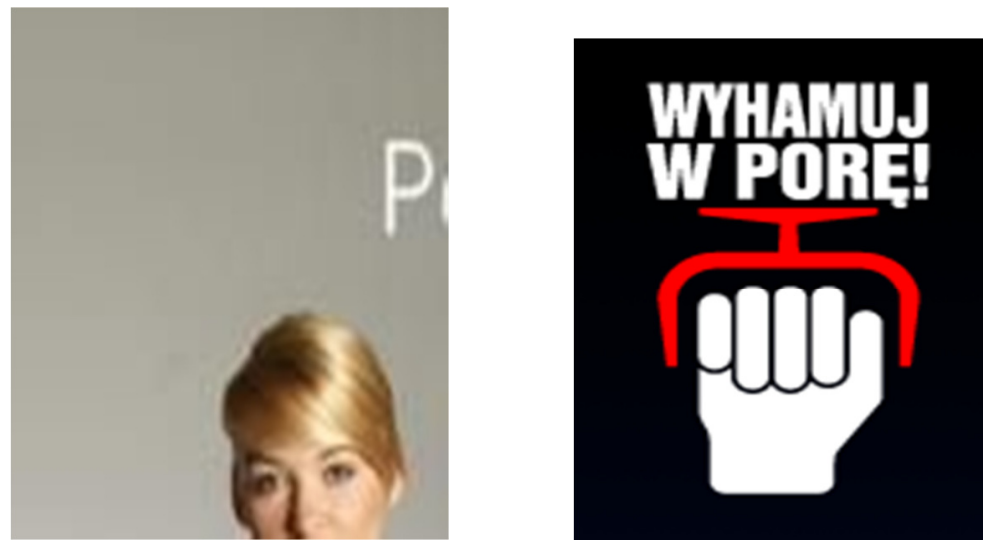

Source: http://www.browary-polskie.pl/spoleczna/kampanie/ and http://www.wyhamujwp ore.pl/.

In 2009, the Polish branch of Alcoholics Anonymous started a campaign warning people of crossing drinking borders, stating that it is scary on the other side. This was illustrated using posters with the text stating "suddenly, it became scary." The campaign was initiated in 2009 by the CAA and Rzeczpospolita, a reputable newspaper (www.kampaniespoleczne.pl 2011). An informational campaign appearing in the newspaper and printed posters (ill. 3) were the primary communication channels. The idea behind the campaign is that alcoholism uses surprise attacks and individuals must be vigilant; it is thus best not to drink. The motto of the campaign is "It is hard to say when a game becomes an illness. Do not try to find out." Surprisingly, this campaign is not featured on the main site of AA (http://aa.org.pl), nor on the newspaper's website (www.rp.pl). 
Illustration 3. The poster with a warning "Suddenly, it became scary"
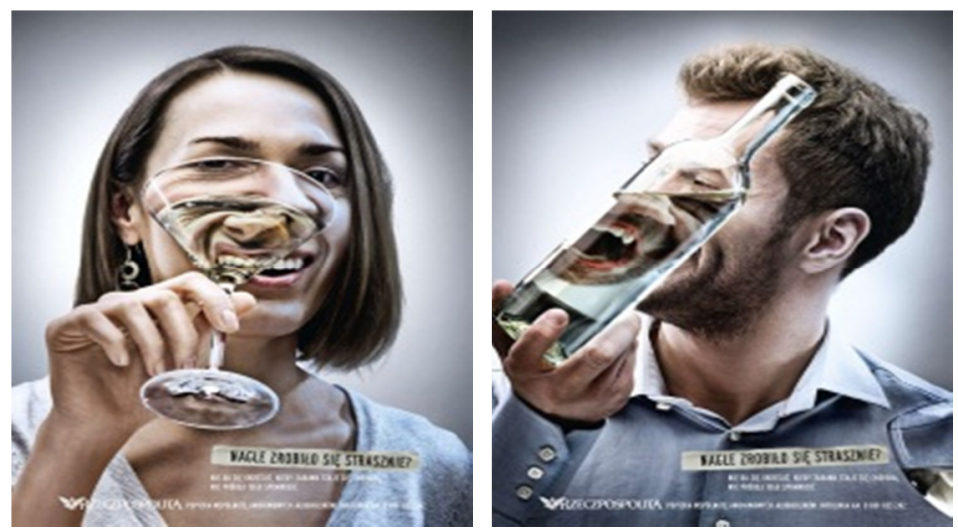

Source: http://www.kampaniespoleczne.pl/kampanie.php?kampania_id=619\&actio $\mathrm{n}=$ szczegoly.

The creator of the campaign titled "Watch Your Drink", the National Bureau for Drug Prevention, has launched this campaign every year since 2007, using posters in 300 popular pubs and discotheque restrooms as the main medium of communication (www.pilnujdrinka.pl 2011). This is an awareness campaign that informs young drinkers that, if they do not watch their drink, someone can put Gamma hydroxybutyrate (GHB) in it - one of the most common substances used in drug-facilitated robbery and assault, incapacitating victims, and lethal when mixed with alcohol. This campaign was supported by many popular websites, including MTV.pl., and the ad was displayed approximately 500,000 times (www.pilnujdrinka.pl). The campaign is playful and uses humor, using Polish words pronounced in English.

The Foundation of Adoptive Families, a nongovernmental Polish organization started in 1997, organized a campaign promoting the idea of a $1 \%$ income tax that Poles could contribute to address the problem of fetal alcohol syndrome babies ("Children with Too Big Experiences", www.ado pcja.org.pl/1procent.php 2011). The Foundation takes care of ill and unwanted children with FAS, providing them with homes, ensuring medical care, treatment, and rehabilitation. The campaign, organized between February and April 2008 (www.adopcja.org.pl/1procent.php 2011), offered a curriculum vitae of the child, with a picture and the description of the child's many diseases, hospital stays, and social rejection. 
Illustration 4. Logo of the campaign "Watch Your Drink" and "CV" from "Children with Too Big Experience" campaign
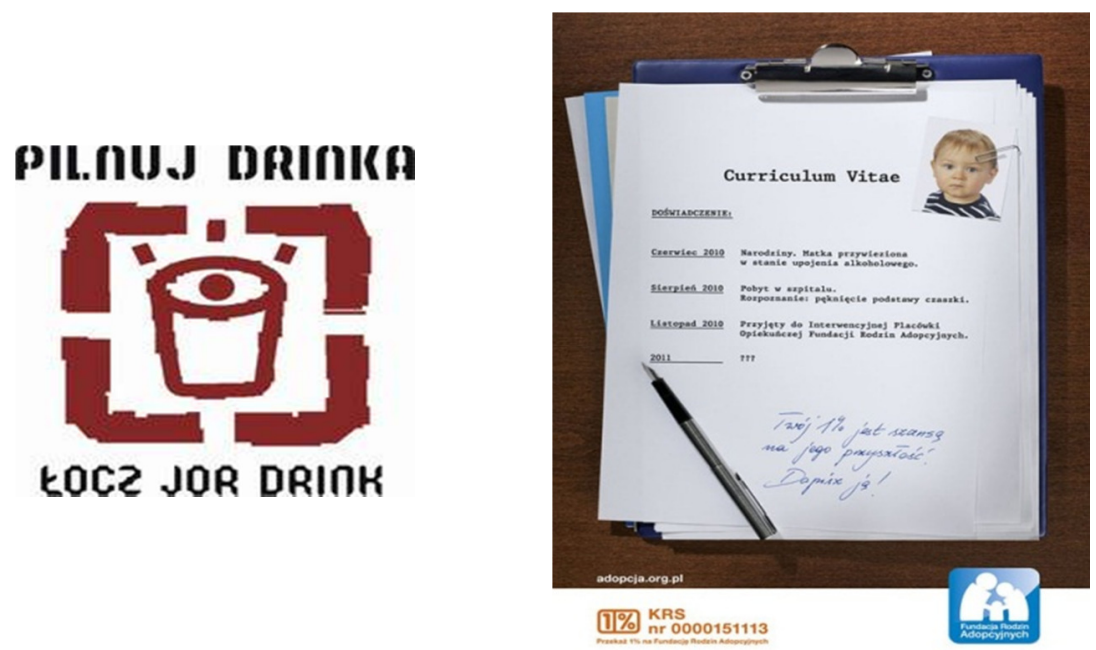

Source: www.narkomania.org.pl and www.kampaniespoleczne.pl/kampanie,1572, dzieci_z_za_duzym_doswiadczeniem.

Next example, "Code against Cancer" campaign, refers to cancer. One of the rules in the Polish Code Against Cancer is to limit alcohol consumption. In September 2008, Maria Sklodowska-Curie Oncology Centre in Warsaw initiated country-wide campaign using animated film, a calendar, and posters in a form of comic strips (www.kampaniespoleczne.pl 2011). Posters were used in 200 cities in Poland, and 200 more were placed in public spaces in Warsaw (www.kampaniespoleczne.pl 2011).

In Poland, it is a tradition to drink vodka to somebody's health, and that is why the campaign "Drink to Somebody's Health" was launched. This is the only regional campaign we examined in the study; the information herein was accessible to us because of one of the authors' direct involvement in the campaign. The campaign was conducted in the West-Pomeranian Province, created by the Marshal's Office of West-Pomeranian Province, and was addressed to drivers, promoting sobriety when driving and showing the ravages caused by alcohol. The campaign was conducted in parallel with the annual program of the Polish police called "Torch", connected with the religious holiday of All Saints, when Poles place candles on graves, and in places on the road where somebody died. The main symbol of this campaign is a wrecked car: in cooperation with police, 5 car wrecks were set on the side of the road in different places as a reminder of what may happen if one drove drunk. 
Illustration 5. "Code against Cancer" comic strips and "Drink to Somebody's Health" poster
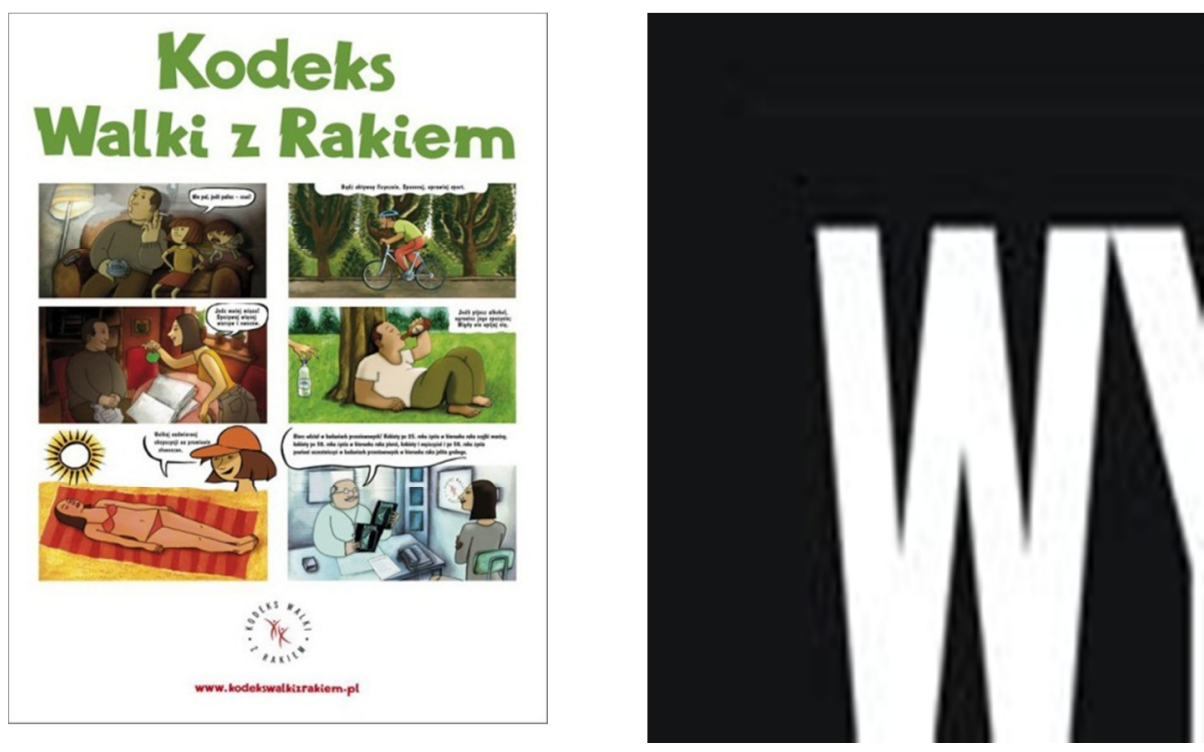

Source: www.kodekswalkizrakiem.pl and http://www.szczecin.kwp.gov.pl/component/cont ent/article/37-ruch-drogowy/5705-start-kampanii-wypi-za-zdrowie-

\section{CAMPAIGN TRAITS}

The campaigns and their themes are summarized below, in Table 1. The different campaigns examined herein, even if they are yearly campaigns, tend to be short in duration, between 6 and 90 days, with one outlier, the "Check if your drinking is safe" campaign, which lasted 261 days - see Table 2.

Table 1. Anti-Drinking Campaigns and Related Themes

\begin{tabular}{|l|l|}
\hline \multicolumn{1}{|c|}{ Title of the Campaign } & \multicolumn{1}{c|}{ Main Theme } \\
\hline Drinking? Do not leave! & Do not drink and drive \\
\hline I am driving sober & Do not drink and drive \\
\hline I swim without alcohol in my blood & Do not drink and swim \\
\hline $\begin{array}{l}\text { Appearances can be deceptive; one's ID } \\
\text { is not }\end{array}$ & $\begin{array}{l}\text { Sellers must not sell alcohol to underage con- } \\
\text { sumers }\end{array}$ \\
\hline Check if your drink is safe & Alcoholics are average individuals - me and you \\
\hline
\end{tabular}


Table 1 Continued

\begin{tabular}{|l|l|}
\hline \multicolumn{1}{|c|}{ Title of the Campaign } & \multicolumn{1}{c|}{ Main Theme } \\
\hline Suddenly, it became scary & Drinking causes you to lose control \\
\hline Watch your drink & $\begin{array}{l}\text { Someone can put GHB in your drink when you } \\
\text { are not looking. }\end{array}$ \\
\hline Children with too big experiences & Stop drinking when you are pregnant \\
\hline Code against cancer & Drinking causes cancer \\
\hline Drink to somebody's health & Do not drink and drive \\
\hline
\end{tabular}

Source: own study.

These campaigns are re-launched every year, but there is no attempt to evaluate their effectiveness. The sponsors of the campaigns are Polish national government bodies (for four of the campaigns), two non-governmental organizations, two associations of alcohol producers, one religious organization, and one local government (for the last campaign). One campaign was co-sponsored with businesses, two with nongovernmental organizations, and one with an organization of producers. See Table 2 . The campaigns generally arouse negative feelings - guilt, shame, and fear. Only two have a positive message, one aimed at retailers, and the second suggesting how to avoid being a victim of GHB tainted drinks. The campaigns are symbolic in terms of the colors used, with black and red dominant in three of the commercials - black symbolizing either a prison life or death in each case, and red symbolizing blood. In terms of other themes, one advertisement contains the photo of a prison, in an effort to produce a strong fear appeal, two illustrate automobiles post-accident, three others show broken glass, four show people, with children and teenagers predominant.

Table 2. Campaigns and Communication Vehicles

\begin{tabular}{|c|c|c|c|c|c|c|c|c|c|c|c|}
\hline \multirow[b]{2}{*}{ Campaign } & \multirow[b]{2}{*}{ 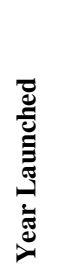 } & \multirow[b]{2}{*}{ 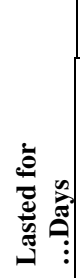 } & \multicolumn{9}{|c|}{ Communication Vehicles } \\
\hline & & & 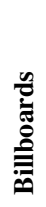 & $\begin{array}{l}\frac{n}{2} \\
\frac{0}{0} \\
\stackrel{0}{0} \\
2\end{array}$ & & 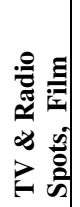 & $\frac{0}{0.0}$ & 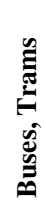 & 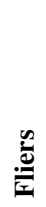 & قُ & 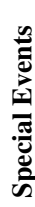 \\
\hline $\begin{array}{l}\text { I am driving } \\
\text { sober }\end{array}$ & 1999 & 67 & $\sqrt{ }$ & $\sqrt{ }$ & $\sqrt{ }$ & $\sqrt{ }$ & $\sqrt{ }$ & $\sqrt{ }$ & & & $\sqrt{ }$ \\
\hline $\begin{array}{l}\text { Drinking? Do not } \\
\text { leave! }\end{array}$ & 2006 & 30 & & & & $\sqrt{ }$ & & $\sqrt{ }$ & $\sqrt{ }$ & & $\sqrt{ }$ \\
\hline
\end{tabular}


Table 2 Continued

\begin{tabular}{|c|c|c|c|c|c|c|c|c|c|c|c|}
\hline \multirow[b]{2}{*}{ Campaign } & \multirow[b]{2}{*}{ 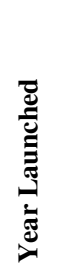 } & \multirow[b]{2}{*}{ 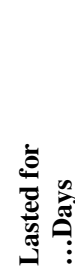 } & \multicolumn{9}{|c|}{ Communication Vehicles } \\
\hline & & & 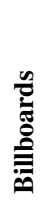 & 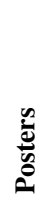 & 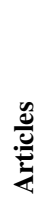 & 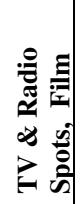 & है & 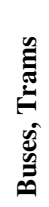 & 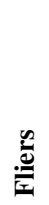 & 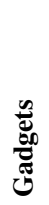 & 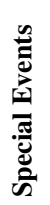 \\
\hline $\begin{array}{l}\text { I swim without } \\
\text { alcohol in my } \\
\text { blood }\end{array}$ & 2007 & 27 & $\sqrt{ }$ & & & & $\sqrt{ }$ & & $\sqrt{ }$ & & $\sqrt{ }$ \\
\hline Watch for a drink & 2007 & 35 & & $\sqrt{ }$ & & & $\sqrt{ }$ & & & & \\
\hline $\begin{array}{l}\text { Code against } \\
\text { cancer }\end{array}$ & 2008 & 90 & $\sqrt{ }$ & $\sqrt{ }$ & $\sqrt{ }$ & $\sqrt{ }$ & & & & $\sqrt{ }$ & \\
\hline $\begin{array}{l}\text { Appearances can } \\
\text { be deceptive; } \\
\text { one's ID is not }\end{array}$ & 2009 & $\begin{array}{l}\text { No } \\
\text { data }\end{array}$ & & $\sqrt{ }$ & & $\sqrt{ }$ & & & & & $\sqrt{ }$ \\
\hline $\begin{array}{l}\text { Check if your } \\
\text { drink is safe }\end{array}$ & 2009 & 261 & $\sqrt{ }$ & $\sqrt{ }$ & & & $\sqrt{ }$ & & & & \\
\hline $\begin{array}{c}\text { Suddenly, it } \\
\text { became scary }\end{array}$ & 2009 & $\begin{array}{l}\text { No } \\
\text { data }\end{array}$ & & & $\sqrt{ }$ & & & & & & \\
\hline $\begin{array}{l}\text { Children with too } \\
\text { big experiences }\end{array}$ & 2011 & 89 & $\sqrt{ }$ & $\sqrt{ }$ & & $\sqrt{ }$ & & & & & \\
\hline $\begin{array}{l}\text { Drinking to } \\
\text { Somebody's } \\
\text { Health }\end{array}$ & 2010 & 6 & & & & & & & & & $\sqrt{ }$ \\
\hline
\end{tabular}

Source: own study.

\section{DISCUSSION}

The present study evaluated ten campaigns used in Poland in an effort to reduce drinking - nine national campaigns, and one regional campaign. The national campaigns comprise an exhaustive list of the campaigns currently used in Poland at the national level. These campaigns are used intermittently to curtail excessive alcohol consumption in a country where alcohol consumption is high.

The campaigns make extensive use of the negative emotions typically associated with efforts to control addictions to alcohol and cigarettes. In the examples provided, the ads use story lines aimed to provoke guilt, shame, and fear. The local campaign in the West-Pomeranian province is almost visceral in its quality, staging accidents on the side of the road. Such strategies may be psychoactive in nature, arousing emotions that potentially may cause a meaningful, well-defined group of viewers to feel extremely anx- 
ious, to feel hostile toward others, or to feel a loss of self-esteem (Hyman 2009). For those most affected, it may even cause anger and self-perceptions of not being able to cope (Bennett 1998; Hyman 2009).

It is noteworthy that even campaigns that have been produced over ten years in Poland have not been assessed, with no attempts in the foreseeable future aimed at evaluating their effectiveness. Moreover, consumption figures continue to show an increase in alcohol despite the campaigns to reduce consumption, and the increase in taxes on alcohol. This increase is attributed to an increase in income for the Polish population: more and more consumers can afford alcoholic drinks, and thus are able to consume in excess. This finding is similar to findings in emerging markets, where cigarette consumption increases in parallel to increases in income (Layton 2009).

Although statistics show that the number of drunk drivers has decreased systematically (see Figure 4), many continue to be stopped by the police for drunk driving - specifically, 173,324 in 2009 , and 165,885 in 2010 (www.statystyka.policja.pl 2011).

Figure 4. Car accidents and number of drunk drivers, 2004-2010

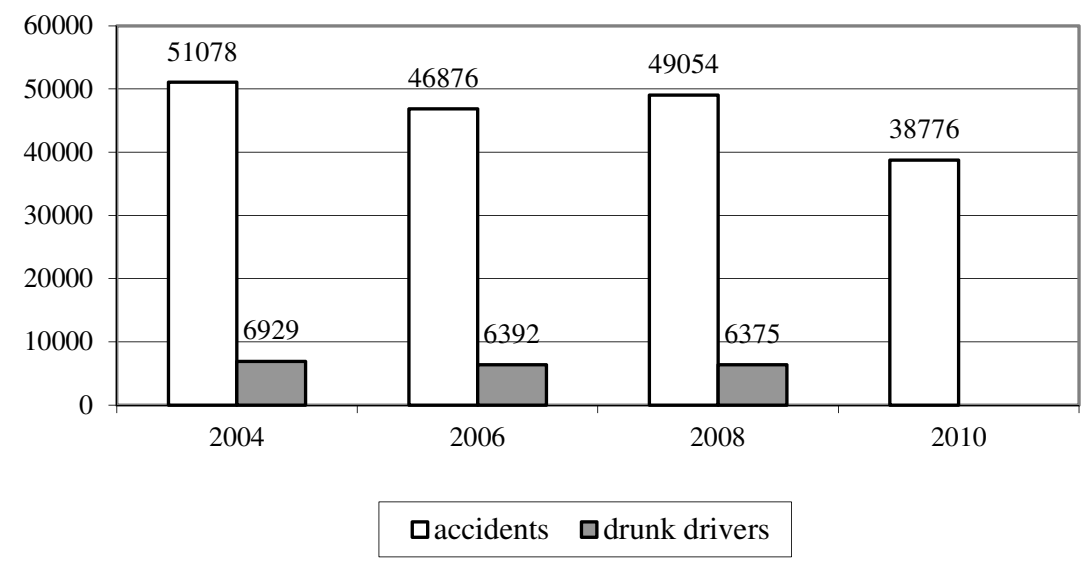

Source: Adapted from: http://www.statystyka.policja.pl/.

These findings are even more encouraging, considering that the number of automobiles has increased from 14,106,078 in 2000 to 21,000,000 in 2011. These positive trends could potentially be further backed by messages that would be aimed at: young men directly, as men between the ages of 20 and 29 account for $80 \%$ of accidents; bicycle riders, as $8 \%$ of accidents are attributed to intoxicated individuals at the age of 50 to 59 , and there present- 
ly are no campaigns aiming at adult bicycle riders (only at children); at weekend leisure activities, as most accidents take place on weekends; since October to December, as poor driving conditions during these months lead to a greater danger of collision. Finally, campaigns use negative communication to change behaviors; it may be more effective to stress positive behavior.

Another challenge for Poland is the many individuals swimming under the influence of alcohol, and drowning as a result (see Table 3). While the statistics are improving every year, and thus it can be concluded that the campaigns promoting safer behavior are effective, it remains surprising that the campaigns are mainly launched at the Baltic Sea, whereas most drownings take place in the lakes and rivers $-71 \%$ in 2010 and $66 \%$ in 2009 (www.statystyka.policja.pl 2011). It is thus advisable that these campaigns acquired a broader focus, targeting all swimmers.

Table 3. Drowning occurrences and drownings attributed to alcohols

\begin{tabular}{|c|c|c|c|}
\hline Year & Drowned [total] & $\begin{array}{c}\text { Drownings at- } \\
\text { tributed to alcohol }\end{array}$ & Percentage \\
\hline 2010 & 369 & 124 & 33.6 \\
\hline 2009 & 359 & 169 & 47.0 \\
\hline 2008 & 352 & 156 & 44.3 \\
\hline 2007 & 376 & 171 & 45.5 \\
\hline 2006 & 451 & 184 & 40.8 \\
\hline
\end{tabular}

Source: Adapted from: http://www.statystyka.policja.pl.

While demarketing actions, such as advertising campaigns against excessive drinking, or drinking under age or while pregnant have greatly contributed to the decrease in the undesirable behavior and have, in fact, led to the development of negative stereotypes of that behavior (Moore 2005), it may be essential for the Polish government to undertake more stringent actions, such as further increasing taxes on alcohol, or instituting more prominent warning labels on alcoholic beverages themselves - appealing to consumers at the point of consumption. The use of alcohol warning labels and messages (or counteradvertising) was assessed as effective in educating the public about alcohol-related risks, curbing alcohol consumption (Bang 1998). Attempts should also be made at unifying the campaigns to ensure that the efforts of the different governmental and nongovernmental organizations and businesses at curtailing excess alcohol consumption are better coordinated. 


\section{CONCLUSIONS}

Poland is a top consumer of alcohol in the European Union, even though it levies high taxes on alcohol consumption and has stringent advertising laws for products containing alcohol. What is particularly disconcerting is that alcohol consumption is increasing, as Poles' salaries have been increasing and more consumers can afford to purchase higher quantities of the product. The present study examines all the current national advertising campaigns in Poland (nine in number), some of which wre initiated over ten years ago, and a local campaign in the West-Pomeranian region, and offers insights into the themes used to persuade consumers to limit their alcohol consumption and to act responsibly when consuming alcohol. The paper also offers actionable suggestions that might change alcohol-related consumption behavior for Polish consumers, such as instituting warning labels and other counteradvertising to educate the public with regard to alcohol-related risks, and thus curb alcohol consumption.

Another approach to controlling alcohol consumption involves creating awareness campaigns that influence consumers to engage in responsible consumption behaviors. There are many who advocate the use of alcohol warning labels and messages (or counteradvertising) as effective tools to educate the public about alcohol-related risks and to help curb alcohol consumption (Bang 1998). Prior studies on alcohol warning messages suggest that their effectiveness is limited to a modest increase in consumer awareness, especially in young adults and heavy users of alcohol (Mazis, Morris, and Swasy 1991, Bang 1998). An awareness increase is particularly reported among men, people 18-29 years of age, heavy drinkers, and those with more education (Scammon, Mayer, and Smith 1991; Graves 1993), and adolescents (MacKinnon 1993; Bang 1998).

A study was conducted to assess the different communication campaigns used in Poland to control excessive drinking. There are currently nine national campaigns and several regional campaigns aimed at changing individuals' alcohol-consumption-related behavior. In this study, we examined the nine campaigns and offer insights into the themes used, and the strategies used to change consumer behavior. The authors studied posters and other advertising materials used to communicate with target audiences, and examined various sources of information about the advertisements and their sponsors.

The campaigns are described in terms of their message and message characteristics, their sponsorship, the vehicles used for communication (billboards, posters, bus advertising, flyers, gadgets), and the cities covered by the campaigns. The study found that the campaigns, even if they are yearly, tend to be short in duration, between 6 and 90 days, with one outlier which 
lasted 261 days. The campaigns are re-launched every year, but there is no attempt to evaluate their effectiveness. The sponsors of the campaigns are Polish national government bodies (for four of the campaigns), two nongovernmental organizations, two associations of alcohol producers, one religious organization, and one local government (for the last campaign). One campaign was co-sponsored with businesses, two with nongovernmental organizations, and one with an organization of producers.

The campaigns generally arouse negative feelings - guilt, shame, and fear. Only two have a positive message, one aimed at retailers, and the second suggesting how to avoid being a victim of GHB tainted drinks. The campaigns are symbolic in terms of the colors used, with black and red dominant in three of the commercials - black symbolizing either a prison life or death in each case, and red symbolizing blood. One campaign used an advertisement containing the photo of a prison, in an effort to produce a strong fear appeal, two illustrated automobiles post-accident, three others show broken glass, four show people, with children and teenagers predominant.

It is noteworthy that even campaigns that were produced over ten years in Poland have not been assessed, with no attempts in the foreseeable future aimed at evaluating their effectiveness. Moreover, consumption figures continue to show an increase in alcohol despite the campaigns to reduce consumption, and the increase in taxes on alcohol. This increase is attributed to an increase in income for the Polish population: more and more consumers afford to purchase alcoholic drinks, and thus are able to consume in excess. This finding is similar to findings in emerging markets, where cigarette consumption increases in parallel to increases in income (Layton 2009).

At the same time, there is a noted and systematic decrease in the number of drunk drivers. This trend could be further sustained if the campaigns focused on automobile accidents were longer, and were particularly focused on the autumn months when most of the crashes take place, and aimed at young men, who account for most of the accidents. With regard to drowning, a campaign that raised the awareness of the ill-fated combination of alcohol and swimming for all consumers would have a much more positive impact than the current campaign that is currently focusing on the Baltic Sea.

We mentioned that although demarketing actions, such as advertising campaigns against extreme drinking have greatly contributed to the reduction in the undesirable behavior, at the same time, in fact, they have led to the development of negative stereotypes of that behavior. Maybe campaigns should be focused on positive situations, behaviors more often. We also suggested that the use of alcohol warning labels and messages (or counteradvertising) was assessed as effective in educating the public about alcoholrelated risks, curbing alcohol consumption. Attempts should also be made at unifying the campaigns to ensure that efforts of the different governmental 
and nongovernmental organizations and businesses at curtailing excess alcohol consumption are better coordinated.

\section{LITERATURE}

Bennett R. (1998), Shame, Guilt and Responses to Non-Profit and Public Sector Ads, "International Journal of Advertising", 17(4).

Craig A.J. (1995), The Effectiveness of Alcohol Warning Labels: A Review and Extension, "American Behavioral Scientist", 38 (4).

Graves K.L. (1993), An Evaluation of the Alcohol Warning Label: A Comparison of the United States and Ontario, Canada in 1990 and 1991, "Journal of Public Policy \& Marketing", 12(1).

Hae-Kyong B. (1998), Analyzing the impact of the liquor industry's lifting of the ban on broadcast advertising, "Journal of Public Policy \& Marketing", Spring.

Hyman M. (2009), Responsible Ads: A Workable Ideal, "Journal of Business Ethics", Vol. 87.

Layton R.A. (2009), On Economic Growth, Marketing Systems, and the Quality of Life, "Journal of Macromarketing", 29(4).

MacKinnon D.P. (1993), The Alcohol Warning Label and Adolescents: The First Year, "American Journal of Public Health", 83(4).

Mazis M.B., Morris L.A., Swasy J.L. (1991), An Evaluation of the Alcohol Warning Label: Initial Survey Results, "Journal of Public Policy \& Marketing”, 10(1).

Moore R.S. (2005), The Sociological Impact of Attitudes Toward Smoking: Secondary Effects of the Demarketing of Smoking, "Journal of Social Psychology", 145(6).

Netemeyer R.G., Durvasula S. (1991), Effects of Consumption Frequency on Believability and Attitudes Toward Alcohol Warning Labels, "Journal of Consumer Affairs", 25(2).

Ornstein S.I., Hanssens D.M. (1985), Alcohol Control Laws and the Consumption of Distilled Spirits and Beer, "Journal of Consumer Research", Vol. 12 (2).

Poel P., Gosepa S., Kroes W., Kruis G., Berkhout W. (2010), The Contribution of the Spirits Industry to the EU Economy, December, Amsterdam, the Netherlands:The European Spirits Companies Liaison Group, the European Spirits Organisation - CEPS, Ernst \& Young Tax Advisors and Regioplan Policy Research.

Scammon D.L., Mayer R.N., Smith K.R. (1991), Alcohol Warnings: How Do You Know When You Have Had One Too Many'?, "Journal of Public Policy \& Marketing", 10(1).

World Bank (2011), World Development Indicators, http://data.worldbank.org/datacatalog/world-development-indicators?cid=GPD_WDI). Accessed on 1/15/2011.

Central Statistical Office 2009, http://www.stat.gov.pl/cps/rde/xbcr/gus/PUBL_oz maly_rocznik_statystyczny_2009.pdf (10.01.2011).

www.adopcja.org.pl/1procent.php (2011) (21.05.2011).

www.browary-polskie.pl (2011), www.browary-polskie.pl/spoleczna/kampanie

/szczegoly.php?gid=\&eid=20\&exd-markupId=5) (18.02.2011).

www.kampaniespoleczne.pl (2011), (12.05.2011). 
www.money.pl/pieniadze (5.0 1.2011).

www.pilesniejedz.pl (2010) (12.12.2010).

www.pilnujdrinka.pl (2011).

http://www.statystyka.policja.pl. (28.07.2011).

www.trzezwosc.pl (2011) (5.02.2011).

www.wiadomosci.gazeta.pl (5.02.2011).

www.wyhamujwpore.pl (2011) (1.01.2011). 